Accepted refereed manuscript of:

Spurgeon DJ, Liebeke M, Anderson C, Kille P, Lawlor A, Bundy JG \& Lahive E (2016) Ecological drivers influence the distributions of two cryptic lineages in an earthworm morphospecies, Applied Soil Ecology, 108, pp. 8-15.

DOI: $\underline{\text { 10.1016/i.apsoil.2016.07.013 }}$

(c) 2016, Elsevier. Licensed under the Creative Commons Attribution-NonCommercial-NoDerivatives 4.0 International http://creativecommons.org/licenses/by-nc-nd/4.0/ 


\section{Ecological drivers influence the distributions of two cryptic lineages in an earthworm morphospecies}

David J. Spurgeon*1, Manuel Liebeke ${ }^{2^{\star}}$, Craig Anderson ${ }^{1,3}$, Peter Kille ${ }^{4}$, Alan Lawlor ${ }^{5}$, Jacob (1) G. Bundy², Elma Lahive ${ }^{1}$

${ }^{1}$ Centre for Ecology and Hydrology, Maclean Building, Benson Lane, Wallingford OX10 8BB, 1

${ }^{2}$ Department of Surgery and Cancer, Faculty of Medicine, Imperial College London, London SW7 2AZ, UK

${ }^{3}$ Biological and Environmental Sciences, School of Natural Sciences, University of Stirling, 5 Stirling, FK9 4LA, UK

$6{ }^{4}$ School of Biosciences, University of Cardiff, Main Building, Museum Avenue, Cardiff CF10

${ }^{5}$ Centre for Ecology and Hydrology, Library Avenue, Bailrigg, Lancaster, LA1 4AP, UK

${ }^{*}$ Current address: Department of Symbiosis, Max Planck Institute for Marine Microbiology,

$$
\text { Bremen, Germany }
$$

3 Corresponding author full contact details: Dr David Spurgeon - Centre for Ecology and

4 Hydrology, Maclean Building, Benson Lane, Crowmarsh Gifford, Wallingford, Oxfordshire

25 OX10 8BB, UK. Tel: 01491772 208, dasp@ceh.ac.uk. 
27 Substantial genetic diversity exists within earthworm morphotypes, such that traditional species designations may be incomplete. It is, however, currently not known whether these different genetic variants show ubiquity or specialty in their distribution across separated sites subject to different climatic, biotic or soil physicochemical factors. Here we report on the results of a survey in which individuals of the Lumbricus rubellus morphotype, a species known to comprise two deeply divergent genetic lineages in England and Wales, were sampled from 26 plots. Sequences from the mitochondrial cytochrome oxidase I gene were used to distinguish lineages for 787 individuals. In conjunction, a range of geographic, climatic, biotic and soil physiochemical variables were also collected for each locality.

Genotyping indicated that Lineage A was more common than Lineage B, comprising $58 \%$ of the collected $L$. rubellus. Six site populations comprised only Lineage A, while only a single site comprised entirely Lineage B. The remaining 20 sites containing both lineages. A multivariate ordination of site variables identified major difference between sites were associated with low $\mathrm{pH}$, organic-rich soils in Western wet upland areas and pollutant levels associated with sites in the South. Earthworm genotype (as proportion of Lineage A) was not correlated with either of these major environmental axes. When individual variables of soil pH and the percentage of soil organic matter, which are known to be key driver of soil species distributions, were investigated as single variables significant relationship with lineage frequency were found. Soil organic matter content was significantly negatively correlated with Lineage A proportion, while $\mathrm{pH}$ was significantly positively correlated. This lineage preference may be related to lineage metabolism and/or behavioral differences.

Measurement of tissue metal concentrations in worms from 17 sites identified a significant site effect in all cases, but a lineage effect only for arsenic (higher Lineage B). Tissue arsenic concentrations varied between lineages, supporting previous observations that there are differences in the way the two lineages have adapted to manage exposure to this metalloid.

Keywords: Biogeography, Earthworm, Cryptic species, pH, Soil organic matter 
Soils contain a wealth of invertebrate biodiversity recognised for their important contributions to ecological processes (Bardgett and van der Putten, 2014; Fitter et al., 2005; Giller, 1996). One key group of species are the "ecosystem engineers": those organisms that modify the physical state of the soil and resource availability for other species. Earthworms are known as a key group of ecosystem engineers in many habitats. They perform a range of physical (aeration, bioturbation, litter fragmentation) and biological (microbial interactions, exudate production) roles in soil (Blouin et al., 2013; Lavelle et al., 1997; Sackett et al., 2013; Umarov et al., 2008). Because of their functional importance, earthworms have emerged as a major taxon for biomonitoring and biomarker assessments of human induced pressures on soil communities (Cluzeau et al., 2012; Rutgers et al., 2009).

67

As soil invertebrate species, including earthworms, have been shown to be sensitive to a range of land use change and pollution impacts (Bundy et al., 2007; Cluzeau et al., 2012), different soil taxa have become a natural focus for research on the relationships between environmental pressures, biodiversity and soil functioning (Bartlett et al., 2010; Leveque et al., 2015; Rutgers et al., 2016). For community studies, a major constraint relates to current uncertainties in earthworm taxonomy. Traditionally earthworm identification has relied on morphology, but the paucity of suitable local keys and problems with application to juveniles has also recently encouraged the use of molecular methods (Dominguez et al., 2015; Emerson et al., 2011; Klarica et al., 2012). These genotyping studies have begun to challenge current understanding of diversity through the identification of genetically distinct cryptic lineages within previously established morphospecies.

80 Earthworm species in which cryptic lineage diversity has to date been identified include 81 Eisenia fetida/andrei (Römbke et al., 2016), Lumbricus terrestris (James et al., 2010), 82 Aporrectodea caliginosa (PerezLosada et al., 2009), Allolobophora chlorotica (King et al., 2008), Amynthas gracilis / Amynthas cortici (Novo et al., 2015) and Lumbricus rubellus. For 
L. rubellus, genotyping studies based on mitochondrial cytochrome oxidase I and II markers have identified as many as 6 cryptic lineages across Europe (Giska et al., 2015), two of which are found in the UK (Andre et al., 2010; Kille et al., 2013). The two UK lineages have 10-15\% divergence for the mitochondrial $\mathrm{COI}$ and COIl sequences. While this implies they may actually be cryptic species, recent analysis of multiple nuclear markers using RADseq has not supported this interpretation, instead suggesting that different $L$. rubellus lineages may actually correspond to a single highly polymorphic species (Giska et al., 2015). Comparative studies of the two lineages in the UK have, nonetheless, identified physiological differences between them, including variation in pheromone production (Jones et al., 2016), maturation time (Anderson et al., 2013), metabolic profiles (Liebeke et al., 2014), mechanism of arsenic adaptation (Kille et al., 2013), trace element metabolism (Andre et al., 2010), and microbiome complement (Pass et al., 2015).

96

97 Despite known biological differences, the extent to which differences in distribution and physiology are related to different geographical, climate and soil physicochemical preferences between the two known UK lineages of $L$. rubellus is not established. The two lineages found co-occur at some, but not all, sites meaning that they have some likely niche divergence that facilitates coexistence (Andre et al., 2010; Giska et al., 2015; Kille et al., 2013). We aim to better understand the nature of the spatial and geochemical drivers of lineage relative abundance, and so here we test the hypothesis that the site distribution of the two cryptic $L$. rubellus lineages is based on one or more geographical, climatic, physiochemical or biotic drivers. We collected and genotyped morphotype L. rubellus at multiple well-characterized sites that differed in their properties to investigate the relationships that determine lineage distributions. Tissue metal concentrations were also measured to assess if trace metal levels could also influence distributions, as could be the case if the two lineages had different sensitivity to specific contaminants. 


\subsection{Site selection}

112 Twenty six sites located across England and Wales (Fig. 1) were visited between four times

113 (for Devon Great Consols Mine and Control, Shipham Mine and Control, Cwmystwyth Mine 114 and Control) and a single visit (for Porton Down, Parys Mountain, Castell, Clydach, Roman

115 Gravel, Didcot) over four separate sampling events from Spring 2011 to Spring 2014. The

116 chosen sites were selected to capture a range of the habitats and soil conditions under which

117 morphotype L. rubellus can be collected. Land-uses covered included arable systems, 118 broadleaf woodland, rough grassland and improved pasture habitats. Sites included both 119 mineral and organic soils, although not true peats.

121 To allow the role of soil geochemistry and pollution status on lineage distribution to be

122 addressed, sites of different known pollution history were sampled. Sites corresponded to 123 three groups with respect to past land-use and associated expected contamination level.

124 These were: 1) sites with no known pollution source (Unpolluted); 2) sites near to industrial 125 facilities expected to be characterised by moderate pollution (Industrial polluted); and 3) sites 126 at abandoned mining sites that can be expected to have high pollution (Mine polluted). For 127 expected polluted sites from categories 2 and 3 , a local control site was also sampled. This 128 reference site was located outside of the area that was expected to be strongly influenced by

129 the main pollution source and so was on soil expected to contain regional background pollutant 130 concentrations.

$132 \quad 2.2$ Site geographical, biological and soil physiochemical characterisation

133 To allow the assessment of environmental drivers relating to lineage distribution, we used both 134 publically available resources as well as our own analyses to gather data on each sites. Site 135 geographical locations were collected as Easting and Northings from 136 www.gridreferencefinder.com and site altitudes from www.freemaptools.com/elevation- 
137 finder.htm. A series of site climate conditions were also assembled from

138 www.metoffice.gov.uk/. These were: annual average maximum temperature, annual average

139 minimum temperature, average January minimum temperature, average July minimum

140 temperature, average annual rainfall, average annual rain days and average annual frost

141 days. Initial visits to each site recorded main land-use (arable, broadleaf woodland, rough

142 grassland and improved pasture) and where present the average sward height of vegetation

143 at collection locations. The site was identified according to the level of shade (open, part

144 shaded, shaded) and the presence of livestock was noted.

146 An initial site survey identified points on the site where morphospecies $L$. rubellus could be

147 found. Thereafter all collections were focussed on these locations. For any one sampling event

148 at each site, between 6 and 25 fully clitellate L. rubellus were collected by digging and hand-

149 sorting from the soil to $20 \mathrm{~cm}$ depth. Generally the required number of worms could be

150 collected within a reasonable search period (approximately $2 \mathrm{~h}$ duration). There were,

151 however, some locations where this was not possible for particular sampling events. Climate

152 factors (notably dry soils), low frequency of adults in the population or the requirement to limit

153 site damage caused by digging were the major constraints. During collection, the presence of

154 other earthworm morphospecies was noted. Only common species were recorded (>5

155 individuals observed). In total 10 other species were found: Aporrectodea caliginosa,

156 Aporrectodea rosea, Aporrectodea longa, Allolobophora chlorotica, Lumbricus castaneus,

157 Dendrobaena rubida, Lumbricus terrestris, Lumbricus festivus, Octolasion cyaneum, and

158 Octolasion tyrtaeum tyrtaeum. At the end of sampling, the L. rubellus collected were washed

159 and blotted dry on-site and then snap frozen in liquid nitrogen before being transfered to the

160 laboratory under dry ice storage.

161

162 Triplicate soil samples from surface to $5 \mathrm{~cm}$ depth were collected from each site collection

163 location. All soil samples were oven dried at $80^{\circ} \mathrm{C}$ to constant weight and then sieved through 
164 a $2 \mathrm{~mm}$ mesh to remove large roots and stones. Total concentrations of aluminium, arsenic,

165 barium, cadmium, cobalt, chromium, copper, iron, lead, manganese, mercury, molybdenum, 166 nickel, selenium, titanium, vanadium, zinc, calcium and total phosphorous were determined in 167 a $1 \mathrm{~g}$ sample of this processed soil following an aqua regia digestion protocol (Arnold et al., 168 2008; Emmett et al., 2010; Spurgeon et al., 2008). Digests were subsequently analysed on a 169 Perkin Elmer Optima 7300 DV inductively coupled plasma optical emission spectrometry 170 instrument. For quality control, an in house reference traceable to BCR-143R (Commission of 171 the European Communities, Community Bureau of Reference) was included with each batch 172 of digestions. Measured concentrations were within $10 \%$ of certified values for all measured 173 elements with the exception of Al where the value was $55 \%$. Organic matter content of each 174 soil sample was measured by proxy using loss on ignition following combustion at $500^{\circ} \mathrm{C}$ 175 (Rowell, 1994) and soil pH was quantified by electrode from a 1:2.5 volume soil:water mix (i.e. 1761 volume soil with 2.5 volumes water added)(International Organisation for Standards, 2005).

\subsection{Lineage assignment by mitochondrial cytochrome oxidase I (COI) sequencing}

179 DNA was extracted from $10 \mathrm{mg}$ of frozen tissue (taken from the tail of each individual using 180 a scalpel) by automated DNA extraction using a Nucleoplex Plants Tissues DNA Extraction 181 Kit (Nucleoplex, Manchester, UK). After DNA quantification using Nanodrop (Thermo 182 Scientific, Willmington, DE), polymerase chain reaction amplification of the COI gene was 183 conducted using a set of established forward (GGTCAACAAATCATAAAGATATTGG) and 184 reverse (TAAACTTCAGGGTGACCAAAAAATCA) primers (Folmer et al., 1994) amplified after 1855 minutes at $95^{\circ} \mathrm{C}$ over 40 cycles of $30 \mathrm{sec} 95^{\circ} \mathrm{C}, 30$ seconds $48^{\circ} \mathrm{C}$ and 60 seconds $48^{\circ} \mathrm{C}$. A 186 sub-set of all PCR products were checked by gel electrophoresis to ensure successful amplification and purified for sequencing using $0.25 \mathrm{U}$ each of Exonuclease I and Shrimp

188 Alkaline Phosphatase (NEB, Hitchin, UK), incubated at $37^{\circ} \mathrm{C}$ for 45 minutes and $80^{\circ} \mathrm{C}$ for 15 minutes. Purified PCR products were then sequenced as in Andre et al. (2010), using ABI

190 PRISM $^{\circledR}$ BigDye v3.1 Terminator Sequencing technology (Applied Biosystems, USA). 
192 Sequences were aligned and trimmed for tree construction using the Maximum Likelihood

193 method and General Time Reversible substitution model with a gamma distribution in Mega

194 v5.01. Sequences for L. rubellus associated with specific mitochondrial lineages already

195 documented in the UK were incorporated into the analysis as anchor sequences (Anderson

196 et al., 2013), with sequences for L. terrestris, L, festivus and L. castaneus included as an out-

197 group. Tree topology was supported by bootstrap analyses over 1000 iterations. Individuals

198 that showed a close relationship with one of the two previously identified UK L. rubellus

199 lineages were identified from the analysis. Any individuals showing intermediate status

200 resulting from probable sequencing errors were excluded from further analysis.

\subsection{Earthworm tissue trace element concentrations}

203 Earthworm tissues from 494 individuals taken from a sub-set of 17 sites (Alice Holt ECN

204 Control, Avonmouth Control, Avonmouth Incinerator, Avonmouth Savalco, Cwmystwyth

205 control, Cwmystwyth mine, Devon Great Consols Control, Devon Great Consols Mine,

206 Drayton ECN Control, Port Talbot Control, Port Talbot blast furnace, Porton Down ECN,

207 Scunthorpe blast furnace, Scunthorpe Control, Shipham control, Shipham mine, Snowdown

208 ECN control) were prepared for analysis (nb samples from remaining sites were lost due to

209 storage issues). These samples were analysed for tissue Al, As, Cd, Co, Cr, Cu, Fe, Mn, Mo,

$210 \mathrm{Ni}, \mathrm{Pb}, \mathrm{Se}, \mathrm{Sr}$ and $\mathrm{Zn}$ concentrations. Whole earthworms, after tail removal for DNA extraction,

211 were initially ground to powder under liquid nitrogen in a cryogenic mill. The powder was

212 freeze-dried and a $100 \mathrm{mg}$ sample digested with $10 \mathrm{ml}$ of $70 \% \mathrm{HNO}_{3}$ (Ultrapure) at $200^{\circ} \mathrm{C}$ for

21315 minutes within a microwave vessel. Samples were run as two batches on a Perkin Elmer

214 DRCII ICP-MS. Each batch included multiple certified reference material samples for TORT-

2152 and DOLT-4 (National Research Council, Canada). Certified values for reference materials

216 corroborated well with measured values. Average recovery was $91 \%$ (range $85 \%$ for Se to

$217110 \%$ for $\mathrm{Pb}$ ) in the first batch of samples and $94.8 \%$ (range 53.9 for $\mathrm{Al}$ to $129 \%$ for $\mathrm{Se}$ ) in the

218 second batch. Recoveries of only two metals, Al and Se, were outside $80 \%$ of certified values 
219 for any run, with 19 of 27 determinations within $10 \%$. With systematic bias absent, acquired

220 data can be used for statistical processing without requirement for recovery correction.

\subsection{Data handling and statistical analysis}

223 The number of $L$. rubellus returning $\mathrm{COI}$ sequences that were closely related to reference 224 sequences from previously collected lineage A and Lineage B individuals were counted for each study site. These were calculated as proportions before being logit transformed as the most appropriate transformation for biological proportion data (Warton and Hui, 2011), with value of zero and one modified by addition and subtraction of half of the lowest proportion respectively. Environmental drivers were established as either categorical (e.g. site type, site shading, livestock presence/absence, earthworm species presence/absence) or as continuous measured variables. The values for soil metal concentrations were log transformed to obtain a Gaussian distribution in accordance with established practice (Davies, 1989).

233 Relationships amongst site geographical, climate and soil variables (after appropriate transformation) were initially investigated using principal component analysis in Minitab 14 (Minitab, PA, USA). This reduces the dimensionality of the original complex dataset in an unsupervised fashion, by successively generating new axes (principal components), that are the linear combinations of the original data that explain greatest overall variance. The principal components (PCs) arising can be interpreted as ordinations representing a summary of environmental factors. Pearson correlations between (logit transformed) proportions of Lineage A individuals at each site and the individual principal component scores were then calculated to investigate the relationships between ordinated site characteristics and genotype. Based on this analysis and prior knowledge, possible individual primary driver

243 variables were identified that were in turn assessed for Pearson correlation with genotype.

244 Because of this key role, percentage organic matter content and soil $\mathrm{pH}$ were selected as 245 focus variables. Site and lineage effects on earthworm tissue log transformed trace element 
246 concentrations were analysed using a mixed model based general linear model in Minitab 14.

247 Within the model, site and lineage were included as fixed variables, with sampling campaign $248 \quad(1-4)$ as a random factor. 
250 High quality $L$. rubellus $\mathrm{COI}$ sequences were obtained from DNA samples taken from 787 earthworms for assignment as either Lineage A or Lineage B individuals. The maximum number of sequences from any one site was 73, from Cwmystwyth Mine, and the minimum 3, from Avonmouth Control (Fig. 1). In total, 457 individuals were assigned as Lineage A, 58\% of the number collected. The remaining 330 (42\%) were assigned as Lineage B. Eight sites (Avonmouth Savalco, Avonmouth Incinerator, Clydach Smelter, Didcot Power Station, Dinas Powys, Parys Mountain, Scunthorpe Control and Scunthorpe) had populations comprising only Lineage A individuals. Seven sites (Avonmouth Control, Castell Mine, Cwmystwyth Control, Cwmystwyth Mine, Drayton ECN Control, Shipham Control and Shipham Mine) contained populations comprised largely Lineage B, although only Castell Mine was exclusively B. All remaining sites had mixed lineage populations, although with more Lineage A than $B$ individuals.

The site geographical, physical and soil characteristics were analysed using principal component analysis. The first PC explained $21.4 \%$ of total variance. A number of parameters were positively correlated with this axis, including soil \% loss on ignition (LOI); soil log Fe, log Co and log Al concentrations; some earthworm species; and site altitude and climate variables including average rainfall and number of rain days. Negatively correlated variables included soil $\mathrm{pH}$; average July max temperature and average temperature; log $\mathrm{Ca}$ and $\log \mathrm{P}$ concentrations; and Easting (Fig 2). This first PC axis could therefore be interpreted as representing a set of variables characterised by the presence of high organic matter, low $\mathrm{pH}$ soils, associated with wetter and colder upland regions located mainly in the West of England and Wales. The second PC axis explained a further $17 \%$ of variation, and was positively associated with Northing and the weather variable of average frost days and average rain days. Variables negatively associated with this axis included pollutant metal concentrations such as $\log \mathrm{Pb}, \log \mathrm{Zn}$ and $\log \mathrm{Cd}$ concentrations (Fig 2). This axis can be interpreted as 
representing a gradient of metal contamination of sites located primarily in the South of

277 England and Wales.

To assess if the site characteristics summarised by the two first PCs potentially act as drivers of lineage distribution, the PC1 and PC2 scores were correlated with the (logit transformed) Lineage A proportion at each location. This did not identify significantly relationships between Lineage A proportion with site PC1 or PC2 score ( $p=0.25$ and $p=0.074$ respectively). As sites PC scores were not significant, we next went on to investigate if individual variables measured are related to the relative frequency of $L$. rubellus lineages. Specifically we selected soil $\mathrm{pH}$ and LOI for initial assessment, as these are established as drivers of patterns of diversity (Griffiths et al., 2011; Raty and Huhta, 2003). Both variables were significantly correlated with logit Lineage A proportion (soil \% OM -0.529, $\mathrm{p}=0.005 ; \mathrm{pH}-0.392, \mathrm{p}=0.048$ ). The nature of these two relationships were summarised by locally weighted scatterplot smoother model fits. These indicate a decline in proportion of Lineage A (higher logit transformed values) as site soil $\%$ LOI increases from $0-20 \%$, thereafter remaining constant. The model fits for $\mathrm{pH}$ indicated an initial decline in the proportion of Lineage A individuals (higher logit transformed values) as $\mathrm{pH}$ increases from 4.5 to 5 , with, thereafter, an increase in frequency (lower logit transformed values) where site $\mathrm{pH}$ increases from 5 to 7.5 (Fig. 4 a,b). Amongst other measured variables, only log soil Ca concentrations $(-0.487, \mathrm{P}=0.012)$ and the average annual number of rain days $(0.433, p=0.027)$ were also significantly correlated with Linage $A$ proportion. Both of these variables are, however, also significantly correlated with soil $\mathrm{pH}$ (Annual rain days: $-0.584, p=0.002$; log soil Ca concentration:-0.751, $\mathrm{p}<0.001$ ) making precise attribution of cause challenging.

Separate univariate models were generated to analyse tissue metal concentrations in relation to collection site and lineage. The collection site had a highly significant $(p<0.001)$ influence on tissue concentrations for all analysed trace elements. This is only to be expected, given

303 that the sites include locations with no history of local pollution, to highly contaminated 
304 industrial and mine sites. Lineage was also a significant factor in the model for $A s(p<0.02)$.

305 This difference is, however, based on only a relatively small difference in average tissue

306 concentrations between lineages across all sites. Thus, average concentrations in Linage A

307 of $10.69(n=300)$ was slightly lower than the average tissue arsenic concentrations of 11.7

$308 \mathrm{mg} / \mathrm{kg}(\mathrm{n}=195)$ for Lineage $\mathrm{B}$, Hence although statistically significant, the absolute magnitude

309 of difference in tissue As concentrations between lineages is small. For all other analysed

310 metals, there was no significant effect of lineage on tissue concentration $(p>0.05)$. 


\section{DISCUSSION}

312 Species distributions can be affected by a range of environmental drivers, including

313 physiological tolerances, dispersal constraints, biotic interactions and anthropogenic

314 influences (Dennis and Hellberg, 2010; Gaston, 2003). Among earthworms, species show

315 preference for certain habitats, for example common compost earthworm species such as

316 Eisenia fetida, Perionyx excavatus and Eudrilus eugeniae preferentially occupy organic matter

317 rich habitats associated with animal manure or composting vegetation (Edwards, 2004).

318 Further, some species also have preference for different soil physiochemical properties. For

319 example, Jaensch et al (2013) found differences in morphospecies preference across different

320 soil $\mathrm{pH}$ classes, with species such as Allolobophora chlorotica, Aporrectodea rosea,

321 Aporrectodea longa and Lumbricus terrestris preferring soils with $\mathrm{pH}>5.6$, and Dendrodrilus

322 rubida, Dendrobaena octaedra and L. rubellus soils with $\mathrm{pH}<5.6$.

324 The UK earthworm fauna is notably denuded, comprising only around 20-25 native species, 325 compared to about 180 species that are found in neighboring France (Bouché, 1972; Sims 326 and Gerard, 1985). The reduced earthworm fauna of the UK can be linked to its recent history

327 of glaciation and the severing of the land bridge to Europe that restricted earthworm 328 colonization after glacial retreat. This influence of quaternary glaciation is consistent with what 329 is known about the current distribution and genetic structure of a range of species across

330 Europe and the UK (Hewitt, 2000). Among UK earthworm species, the majority show a 331 widespread and cosmopolitan distribution (Boag et al., 1997; Carpenter et al., 2012; Rutgers 332 et al., 2016; Sims and Gerard, 1985). Habitat preferences are known, such as those for pH 333 and for organic rich habitats as discussed previously, however the spatial heterogeneity of 334 terrestrial habitats means that at coarse recording scales (e.g. $10 \mathrm{~km}^{2}$ or even $1 \mathrm{~km}^{2}$ ), a 335 significant proportion of UK earthworm species may be present in any given sampling area 336 (e.g. a mixed land-use area subject to comprehensive earthworm sampling within different 337 vegetation stands and habitats). 
339 Genetic marker studies have identified deeply divergent cryptic lineages within many common

340 UK earthworm morphospecies based on mitochondrial or nuclear genetic marker analysis. An

341 active debate currently surrounds the question of whether these cryptic lineages correspond

342 to cryptic species or highly polymorphic species variants (Blakemore et al., 2010; Giska et al.,

343 2015; King et al., 2008). In the specific case of L. rubellus, the presence of cryptic lineages is established from studies conducted from measurement of highly divergent (13-15\%) sequences for both of the cytochrome oxidase I and II mitochondrial genes (Andre et al., 2010;

346 Donnelly et al., 2014; Kille et al., 2013). Pan-European studies have shown that at continental 347 scale, morphotype L. rubellus may comprise of 5 or more such deeply divergent lineages 348 (Giska et al., 2015), two of which were here found across sites in England and Wales (Fig 1). 349 Recently RADseq analysis suggests that cryptic $L$. rubellus lineages may represent a case of 350 a highly polymorphic single species rather than true cryptic species (Giska et al., 2015). 351 Nonetheless, previous studies of the lineage physiology have identified a number of 352 differential responses between lineages (as previously outlined notably for the two UK 353 lineages). For example, Jones et al. (2016) found that the two lineage were favorably attracted 354 to soils that had previously been worked by earthworm of their own rather than the alternative lineage. These results suggests that pheromone attractants may allow mate selection in mix populations,. such as those that are found at the majority of our sampled site. Such selection has the potential to underpin lineage differences in habitat preference and, as a consequence, different spatial distributions at local scale.

360 Earthworms are key ecosystem engineers for the role that play an important role in the creating of the spatial structure and chemistry of the soil habitat through bioturbation, litter degradation and nutrient cycling (Edwards, 2004; Lavelle et al., 1997; Liebeke et al., 2015). The extent to which the divergent lineages of common earthworm species overlap in respect of habitat preference will be an important determinant of morphospecies contributions to different ecosystem processes across space and time. The analysis here suggests that, in the case of the two UK lineages of $L$. rubellus, there are ecological drivers of distribution. 
367 Individually, soil $\mathrm{pH}$ and \% OM were both significant correlated with the proportions of $L$.

368 rubellus Lineage A (and conversely Lineage B) collected across the 26 sample sites. These

369 two measurement parameters were selected for particular focus because they are recognized

370 as important environmental drivers of the distribution of a number of soil taxa (Cassagne et

371 al., 2003; Griffiths et al., 2011; Raty and Huhta, 2003). Additionally, there are also correlations with other climate and soil variable that are themselves know to influence soil pH through soil

373 geochemistry and leaching.

375 Different soil pH preferences have direct effects on earthworm traits including reproduction, growth and survival (Baker and Whitby, 2003; Spurgeon et al., 2006; Van Gestel et al., 1992).

L. rubellus is tolerant of relatively low $\mathrm{pH}$, being commonly (and even preferentially) found in moderately acidic soils (Jaensch et al., 2013). Results here suggest that this cosmopolitan nature could partly arise from different lineage $\mathrm{pH}$ preferences, with Lineage $\mathrm{B}$ found in more acid habitats from pH 4.5 to 5.5 and Lineage A preferentially in nearer neutral pHs of 5.5 and above. Thus, within the current study, Lineage B was absent from 6 of 26 sampled sites, while Lineage A was found at all except one of the sampled sites. The detailed genetics of the two cryptic lineages may provide some clues to the basis of such differences. Studies of mitochondrial and genetic marker genes have established that Lineage B has lower genetic diversity of measured traits than Lineage A (Donnelly et al., 2014; Kille et al., 2013). This suggests that Lineage B may have undergone a population bottleneck that restricted the genetic diversity, and possibly, the colonization capacity of this lineage.

The strongest correlate of lineage frequencies was soil organic matter (\% loss on ignition). The fresh and partially degraded soil organic component provides earthworms with food. It is, therefore, possible that this association is driven by different dietary requirements of the two lineages, as has been recognized for different earthworm species (Piearce, 1978). However, in addition to acting as food, soil organic matter also contributes to soil structure and moisture

394 retention. Earthworms are known to be sensitive to soil texture, with regional studies linking 
species distributions to soil sand, clay and organic matter content (Joschko et al., 2006;

396 Salome et al., 2011). Soils lacking in organic matter are also vulnerable to prolonged periods

397 of high soil moisture deficit. This can be challenging for earthworms given their critical need

398 to retain water balance. The significant correlation with site average rain days also points to a

399 possible influence of soil hydrology on distributions. Metabolomic analyses have identified that many earthworm species contain a high number of betaines which likely act as osmolytes that help to retain soil water balance (Liebeke and Bundy, 2013). Any differences in the extent of such protection between lineages may influence colonization ability for more drought susceptible soils.

Although there is correlation of lineage frequency with both soil $\mathrm{pH}$ and soil organic matter, the fact that these two soil variables are co-correlated to other environmental variables makes it hard to unequivocally assign them as the major drivers of lineage distribution. For example, high organic matter/low pH soils are more common in the West of England and Wales than in

409 the East. This geographic relationship could potentially be associated with different 410 recolonization histories for the two lineages, e.g. perhaps recolonization from different glacial 411 refugia (Hewitt, 2000). However, as there is no significant correlation of Easting to lineage 412 proportion, this seems less likely than direct effects of soil organic matter/pH. Ultimately, to 413 tease apart the drivers of lineage preference, higher resolution collection and mapping and 414 experimental manipulation of habitats would be required.

416 Differences in physiology that separate species in relation to habitat preference could also 417 affect the way that the two lineages handle and accumulate different trace elements. For the 418 site-level analysis, the soil concentrations of major pollutant metals were correlated with PC2, 419 which was not associated with lineage. For the individual analysis of tissue metals, arsenic 420 was the only one found to vary with lineage (significantly higher in Lineage B individuals). 421 Previous work has indicated that the two lineages differ in the genetic mechanisms underlying 422 the development of arsenic tolerance. Analysis of amplified fragment length polymorphisms 
423 indicated that Lineage A showed differences in patterns of nuclear markers indicating genetic

424 tolerance, while Lineage B showed a difference in DNA methylation patterning, but not genetic

425 differences (Kille et al., 2013). The observed difference here in As accumulation between

426 lineages across sites suggests that these genetic differences lead to phenotypic differences

427 in the handling of As.

428

\section{CONCLUSIONS}

430 Earthworms represent 'super-sentinels' exploited for environmental monitoring and 431 ecotoxicology, as well as being keystone soil engineers essential for soil quality. The 432 identification of possible drivers of species and lineage distributions has potential implications 433 for their use in environmental assessment as well as in studies of ecosystem service delivery.

434 For example, when assessing biodiversity effects of pollution and land-use change it may be 435 valuable to consider the occurrence of different lineages to understand how populations may 436 adapt to change through changes in lineage frequency. This analysis may be required 437 because the two widespread cryptic lineages of $L$. rubellus differ in their habitat preferences 438 with frequencies changing as conditions change. Given that bacterial communities are also 439 known to differ in relation to soil $\mathrm{pH}$, then difference in the nature and strengths of earthworm 440 and microbial interactions can be expected between lineages. These relationships between 441 soil macrofauna and microbes are key to soil carbon turnover, nutrient cycling and soil 442 structural characteristics and this aspect warrants further investigation. Earthworms are also 443 valuable for metal biomonitoring. Our results suggest that the lineages behave identically with 444 respect to metal bioaccumulation, with the exception of As. Thus, selection of morphotype $L$. 445 rubellus will provide a coherent picture of metal accumulation independent of lineage, unless 446 As is a specific focus of any assessment. 


\section{6. ACKNOWLEDGMENTS}

448 This study was supported by the Natural Environment Research Council (NERC), UK, under 449 grant number NE/H00973/1. We thank Dr Rachael Madison and Dr Judith Garforth for help 450 with earthworm and soil collection and the Forestry Commission, ADAS and Countryside 451 Commission for Wales for allowing access to Environmental Change Network (ECN) sites and 452 Alice Holt, Snowdon and Drayton Experimental Frame respectively. 


\section{REFERENCES}

454 Anderson, C.J., Kille, P., Lawlor, A.J., Spurgeon, D.J., 2013. Life-history effects of arsenic 455 toxicity in clades of the earthworm Lumbricus rubellus. Environ Pollut 172, 200-207.

456 Andre, J., King, R.A., Stürzenbaum, S.R., Kille, P., Hodson, M.E., Morgan, A.J., 2010.

457 Molecular genetic differentiation in earthworms inhabiting a heterogeneous $\mathrm{Pb}$-polluted 458 landscape. Environ Pollut 158, 883-890.

459 Arnold, B.E., Hodson, M.E., Charnock, J., Peijnenburg, W., 2008. Comparison of subcellular 460 partitioning, distribution, and internal speciation of $\mathrm{Cu}$ between $\mathrm{Cu}$-tolerant and naive 461 populations of Dendrodrilus rubidus Savigny. Environ Sci Technol 42, 3900-3905.

462 Baker, G.H., Whitby, W.A., 2003. Soil pH preferences and the influences of soil type and 463 temperature on the survival and growth of Aporrectodea longa (Lumbricidae). Pedobiologia $464 \quad 47,745-753$.

465 Bardgett, R.D., van der Putten, W.H., 2014. Belowground biodiversity and ecosystem 466 functioning. Nature 515, 505-511.

467 Bartlett, M.D., Briones, M.J.I., Neilson, R., Schmidt, O., Spurgeon, D., Creamer, R.E., 2010. 468 A critical review of current methods in earthworm ecology: From individuals to populations. 469 European Journal of Soil Biology 46, 67-73.

470 Blakemore, R.J., Kupriyanova, E.K., Grygier, M.J., 2010. Neotypification of Drawida 471 hattamimizu Hatai, 1930 (Annelida, Oligochaeta, Megadrili, Moniligastridae) as a model 472 linking mtDNA (COI) sequences to an earthworm type, with a response to the 'Can of Worms' 473 theory of cryptic species. Zookeys, 1-29.

474 Blouin, M., Hodson, M.E., Delgado, E.A., Baker, G., Brussaard, L., Butt, K.R., Dai, J., 475 Dendooven, L., Peres, G., Tondoh, J.E., Cluzeau, D., Brun, J.J., 2013. A review of earthworm 476 impact on soil function and ecosystem services. Eur. J. Soil Sci. 64, 161-182. 
477 Boag, B., Palmer, L.F., Neilson, R., Legg, R., Chambers, S.J., 1997. Distribution, prevalence 478 and intensity of earthworm populations in arable land and grassland in Scotland. Ann. Appl. 479 Biol. 130, 153-165.

480 Bouché, M.B., 1972. Lombriciens de france. Ecologie et systématique. Institut national de la 481 Recherche Agronomique, Paris.

482 Bundy, J.G., Keun, H., Sidhu, J.K., Spurgeon, D.J., Svendsen, C., Kille, P., Morgan, A.J., 2007. Metabolic profile biomarkers of metal contamination in a sentinel terrestrial species are applicable across multiple sites. Environ Sci Technol 41, 4458-4464.

Carpenter, D., Sherlock, E., Jones, D.T., Chiminoides, J., Writer, T., Neilson, R., Boag, B.,

Keith, A.M., Eggleton, P., 2012. Mapping of earthworm distribution for the British Isles and 487 Eire highlights the under-recording of an ecologically important group. Biodivers. Conserv. 488 $21,475-485$.

489

Cassagne, N., Gers, C., Gauquelin, T., 2003. Relationships between Collembola, soil chemistry and humus types in forest stands (France). Biol. Fertil. Soils 37, 355-361.

491 Cluzeau, D., Guernion, M., Chaussod, R., Martin-Laurent, F., Villenave, C., Cortet, J., Ruiz492 Camacho, N., Pernin, C., Mateille, T., Philippot, L., Bellido, A., Rouge, L., Arrouays, D., 493 Bispo, A., Peres, G., 2012. Integration of biodiversity in soil quality monitoring: Baselines for 494 microbial and soil fauna parameters for different land-use types. European Journal of Soil 495 Biology 49, 63-72.

496 Davies, B.E., 1989. Data handling and pattern recognition for contaminated soils. Environ. 497 Geochem. Health 11, 137-143.

498 Dennis, A.B., Hellberg, M.E., 2010. Ecological partitioning among parapatric cryptic species. 499 Mol. Ecol. 19, 3206-3225. 
500 Dominguez, J., Aira, M., Breinholt, J.W., Stojanovic, M., James, S.W., Perez-Losada, M., 501 2015. Underground evolution: New roots for the old tree of lumbricid earthworms. Mol. 502 Phylogenet. Evol. 83, 7-19.

503 Donnelly, R.K., Harper, G.L., Morgan, A.J., Pinto-Juma, G.A., Bruford, M.W., 2014.

504 Mitochondrial DNA and morphological variation in the sentinel earthworm species Lumbricus 505 rubellus. European Journal of Soil Biology 64, 23-29.

506 Edwards, C.A., 2004. Earthworm Ecology, 2 ed. CRC Press, Boca Raton, Florida, USA, p. 507441.

508 Emerson, B.C., Cicconardi, F., Fanciulli, P.P., Shaw, P.J.A., 2011. Phylogeny, 509 phylogeography, phylobetadiversity and the molecular analysis of biological communities.

510 Philosophical Transactions of the Royal Society B-Biological Sciences 366, 2391-2402.

511 Emmett, B.A., Reynolds, B., Chamberlain, P.M., Rowe, E., Spurgeon, D., Brittain, S.A., 512 Frogbrook, Z., Hughes, S., Lawlor, A.J., Poskitt, J., Potter, E., Robinson, D.A., Scott, A., 513 Wood, C., Woods, C., 2010. Countryside Survey: Soils Report from 2007. NERC Centre for

514 Ecology and Hydrology, Wallingford, UK.

515 Fitter, A.H., Gilligan, C.A., Hollingworth, K., Kleczkowski, A., Twyman, R.M., Pitchford, 516 J.W., Programme, N.S.B., 2005. Biodiversity and ecosystem function in soil. Funct. Ecol. 19, $517 \quad 369-377$.

518 Folmer, O., Black, M., Hoeh, W., Lutz, R., Vrijenhoek, R., 1994. DNA primers for 519 amplification of mitochondrial cytochrome c oxidase subunit I from diverse metazoan 520 invertebrates. Mol. Mar. Biol. Biotechnol. 3, 294-299.

521 Gaston, K.J., 2003. The Structure and Dynamics of Geographic Ranges. Oxford University 522 Presss, Oxford, UK.

523 Giller, P.S., 1996. The diversity of soil communities, the 'poor man's tropical rainforest'. 524 Biodivers. Conserv. 5, 135-168. 
525 Giska, I., Sechi, P., Babik, W., 2015. Deeply divergent sympatric mitochondrial lineages of the earthworm Lumbricus rubellus are not reproductively isolated. BMC Evol. Biol. 15.

527 Griffiths, R.I., Thomson, B.C., James, P., Bell, T., Bailey, M., Whiteley, A.S., 2011. The 528 bacterial biogeography of British soils. Environ. Microbiol. 13, 1642-1654.

529 Hewitt, G., 2000. The genetic legacy of the Quaternary ice ages. Nature 405, 907-913.

530 International Organisation for Standards, 2005. Determination of pH., Geneva, Switzerland.

531 Jaensch, S., Steffens, L., Hoefer, H., Horak, F., Ross-Nickoll, M., Russell, D., Toschki, A., 532 Roembke, J., 2013. State of knowledge of earthworm communities in German soils as a basis 533 for biological soil quality assessment. Soil Organisms 85, 215-233.

534 James, S.W., Porco, D., Decaens, T., Richard, B., Rougerie, R., Erseus, C.A.F.N.J.S.W., Porco, 535 D., Decaens, T., Richard, B., Rougerie, R., Erseus, C., 2010. DNA Barcoding Reveals Cryptic 536 Diversity in Lumbricus terrestris L., 1758 (Clitellata): Resurrection of L. herculeus (Savigny, 1826). PLoS One 5, e15629.

Jones, G.L., Wills, A., Morgan, A.J., Thiomas, R.J., Kille, P., Novo, M., 2016. The worm has turned: Behavioural drivers of reproductive isolation between cryptic lineages. Soil Biol.

540 Biochem. 98, 11-17.

541 Joschko, M., Fox, C.A., Lentzsch, P., Kiesel, J., Hierold, W., Kruck, S., Timmer, J., 2006. Spatial analysis of earthworm biodiversity at the regional scale. Agric. Ecosys. Environ. 112, 367-380.

544 Kille, P., Andre, J., Anderson, C., Ang, H.N., Bruford, M.W., Bundy, J.G., Donnelly, R., 545 Hodson, M.E., Juma, G., Lahive, E., Morgan, A.J., Sturzenbaum, S.R., Spurgeon, D.J., 2013. 546 DNA sequence variation and methylation in an arsenic tolerant earthworm population. Soil 547 Biol. Biochem. 57, 524-532.

548 King, R.A., Tibble, A.L., Symondson, W.O.C., 2008. Opening a can of worms: unprecedented 549 sympatric cryptic diversity within British lumbricid earthworms. Mol. Ecol. 17, 4684-4698. 

genes in earthworms - Implications for identification, phylogenetics, and discovery of cryptic species. Soil Biol. Biochem. 45, 23-30.

Lavelle, P., Bignell, D., Lepage, M., Wolters, V., Roger, P., Ineson, P., Heal, O.W., Dhillon, S., 1997. Soil function in a changing world: the role of invertebrate ecosystem engineers. European Journal of Soil Biology 33, 159-193.

Leveque, T., Capowiez, Y., Schreck, E., Mombo, S., Mazzia, C., Foucault, Y., Dumat, C., 2015. Effects of historic metal(loid) pollution on earthworm communities. Sci Total Environ $511,738-746$.

Liebeke, M., Bruford, M.W., Donnelly, R.K., Ebbels, T.M.D., Hao, J., Kille, P., Lahive, E., Madison, R.M., Morgan, A.J., Pinto-Juma, G.A., Spurgeon, D.J., Svendsen, C., Bundy, J.G., 2014. Identifying biochemical phenotypic differences between cryptic species. Biol. Lett. 10 . Liebeke, M., Bundy, J.G., 2013. Biochemical diversity of betaines in earthworms. Biochem. Biophys. Res. Commun. 430, 1306-1311.

564 Liebeke, M., Strittmatter, N., Fearn, S., Morgan, A.J., Kille, P., Fuchser, J., Wallis, D., 565 Palchykov, V., Robertson, J., Lahive, E., Spurgeon, D.J., McPhail, D., Takats, Z., Bundy, J.G., 2015. Unique metabolites protect earthworms against plant polyphenols. Nature Comms. 6.

567 Novo, M., Cunha, L., Maceda-Veiga, A., Talavera, J.A., Hodson, M.E., Spurgeon, D., Bruford, M.W., Morgan, A.J., Kille, P., 2015. Multiple introductions and environmental factors 569 affecting the establishment of invasive species on a volcanic island. Soil Biol. Biochem. 85, $570 \quad 89-100$.

571 Pass, D.A., Morgan, A.J., Read, D.S., Field, D., Weightman, A.J., Kille, P., 2015. The effect 572 of anthropogenic arsenic contamination on the earthworm microbiome. Environ. Microbiol. $17,1884-1896$. 
574 PerezLosada, M., Ricoy, M., Marshall, J.C., Dominguez, J., 2009. Phylogenetic assessment of the earthworm Aporrectodea caliginosa species complex (Oligochaeta: Lumbricidae) based on mitochondrial and nuclear DNA sequences. Mol. Phylogenet. Evol. 52, 293-302.

Piearce, T.G., 1978. Gut contents of some Lumbricid earthworms. Pedobiologia 18, 153-157.

578 Raty, M., Huhta, V., 2003. Earthworms and pH affect communities of nematodes and 579 enchytraeids in forest soil. Biol. Fertil. Soils 38, 52-58.

580 Römbke, J., Aira, M., Backeljau, T., Breugelmans, K., Domínguez, J., Funke, E., Graf, N., 581 Hajibabaei, M., Pérez-Losada, M., Porto, P.G., Schmelz, R.M., Vierna, J., Vizcaíno, A., 582 Pfenninger, M., 2016. DNA barcoding of earthworms (Eisenia fetida/andrei complex) from 28 583 ecotoxicological test laboratories. Appl. Soil Ecol. doi:10.1016/j.apsoil.2015.02.010.

584 Rowell, D.L., 1994. Soil Science: Methods and Applications. Longman Scientific and 585 Technical, Harlow, UK.

586 Rutgers, M., Orgiazzi, A., Gardi, C., Roembke, J., Jaensch, S., Keith, A.M., Neilson, R., Boag, 587 B., Schmidt, O., Murchie, A.K., Blackshaw, R.P., Peres, G., Cluzeau, D., Guernion, M., 588 Briones, M.J.I., Rodeiro, J., Pineiro, R., Diaz Cosin, D.J., Paulo Sousa, J., Suhadolc, M., Kos, 589 I., Krogh, P.-H., Faber, J.H., Mulder, C., Bogte, J.J., van Wijnen, H.J., Schouten, A.J., de 590 Zwart, D., 2016. Mapping earthworm communities in Europe. Appl. Soil Ecol. 97, 98-111.

591 Rutgers, M., Schouten, A.J., Bloem, J., vanEekeren, N., deGoede, R.G.M., Akkerhuis, G., 592 vanderWal, A., Mulder, C., Brussaard, L., Breure, A.M., 2009. Biological measurements in a 593 nationwide soil monitoring network. Eur. J. Soil Sci. 60, 820-832.

594 Sackett, T.E., Smith, S.M., Basiliko, N., 2013. Indirect and direct effects of exotic earthworms 595 on soil nutrient and carbon pools in North American temperate forests. Soil Biol. Biochem. 57, 459-467. 
597 Salome, C., Guenat, C., Bullinger-Weber, G., Gobat, J.M., Le Bayon, R.C., 2011. Earthworm 598 communities in alluvial forests: Influence of altitude, vegetation stages and soil parameters. 599 Pedobiologia 54, S89-S98.

600 Sims, R.W., Gerard, B.M., 1985. Earthworms. Linnean Society and the Estuarine and 601 Brackish-Water Sciences Association, London.

602 Spurgeon, D.J., Lofts, S., Hankard, P.K., Toal, M., McLellan, D., Fishwick, S., Svendsen, C., 603 2006. Effect of $\mathrm{pH}$ on metal speciation and resulting metal uptake and toxicity for earthworms.

604 Environ Toxicol Chem 25, 788-796.

605 Spurgeon, D.J., Rowland, P., Ainsworth, G., Rothery, P., Long, S., Black, H.I.J., 2008. 606 Geographical and pedological drivers of distribution and risks to soil fauna of seven metals 607 (Cd, Cu, Cr, Ni, Pb, V and Zn) in British soils. Environ Pollut 153, 273-283.

608 Umarov, M.M., Striganova, B.R., Kostin, N.V., 2008. Specific features of nitrogen 609 transformation in the gut and coprolites of earthworms. Biol. Bulletin 35, 643-652.

610 Van Gestel, C.A.M., Dirven-Van Breemen, E.M., Baerselman, R., 1992. Influence of 611 environmental conditions on the growth and reproduction of the earthworm Eisenia andrei in 612 an artificial soil substrate. Pedobiologia 36, 109-120.

613 Warton, D.I., Hui, F.K.C., 2011. The arcsine is asinine: the analysis of proportions in ecology. 614 Ecology 92, 3-10. 


\section{LEGENDS TO FIGURES}

617

618 Figure 1. Location of collection sites and the proportion of Lineage A (dark blue shading) and

619 Lineage B (light yellow shading) L. rubellus based on the total number of collected and 620 assigned genotyped individual (given in brackets) for the 26 sites visit over four separate 621 collection campaigns

622

623 Figure 2. Principal component analysis results show the ordination of site geographical, 624 climatic, biotic and soil chemical variables of sample sites showing the major related site 625 characteristic variables.

626

627 Figure 3. Boxplots showing median (centre line), upper and lower quartile (box limits) and 628 upper and 95\% confidence intervals (whiskers) of trace metal concentrations measured 629 across 17 samples site for assigned Lineage A and Lineage B L. rubellus.

630

631 Figure 4. Scatterplots with fitted locally weighted scatterplot smoother line of proportion of 632 Lineage A L. rubellus in relation to (a) Soil \% OM and (b) soil pH. 
FIG. 1

635

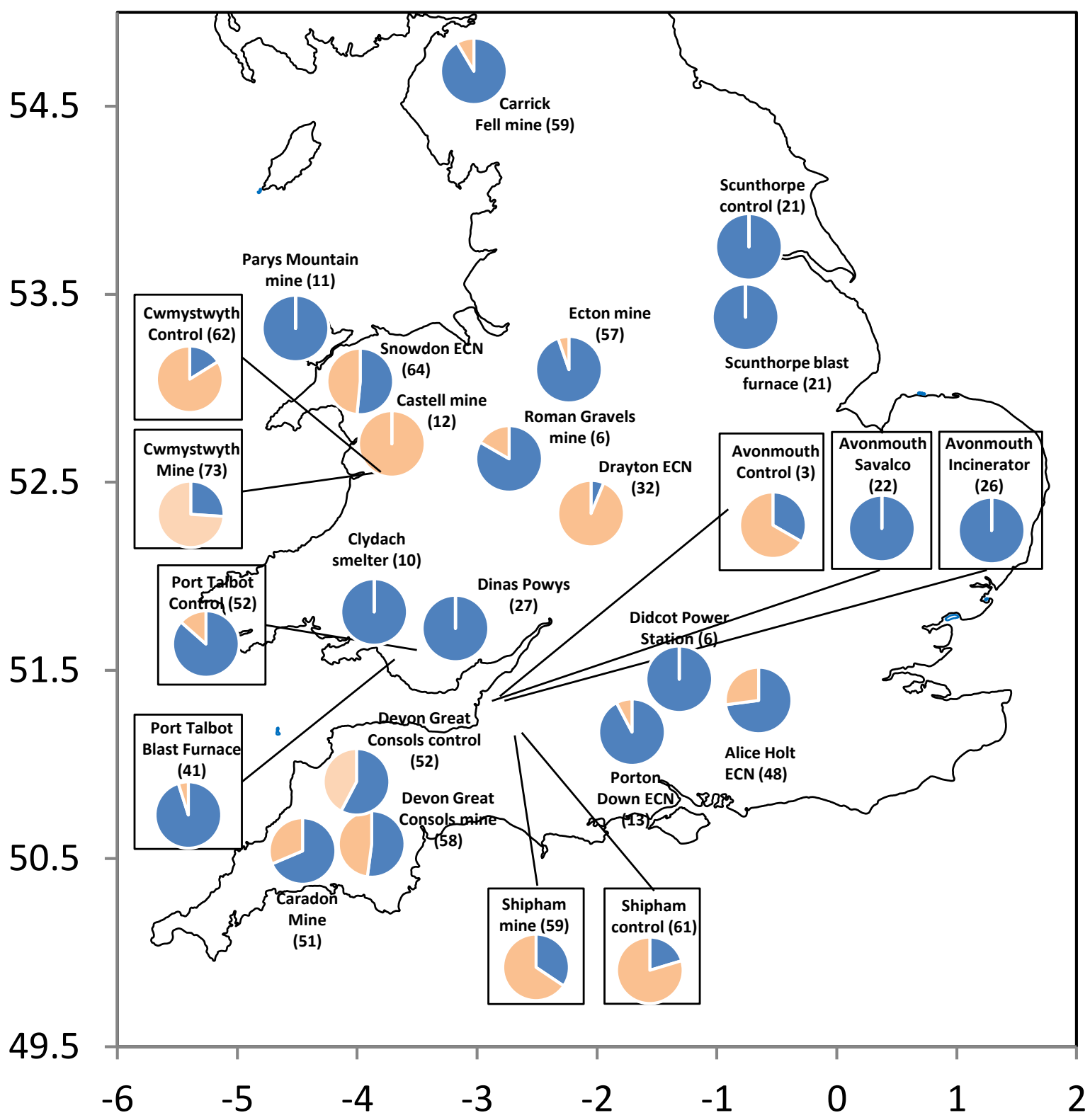


FIG. 2

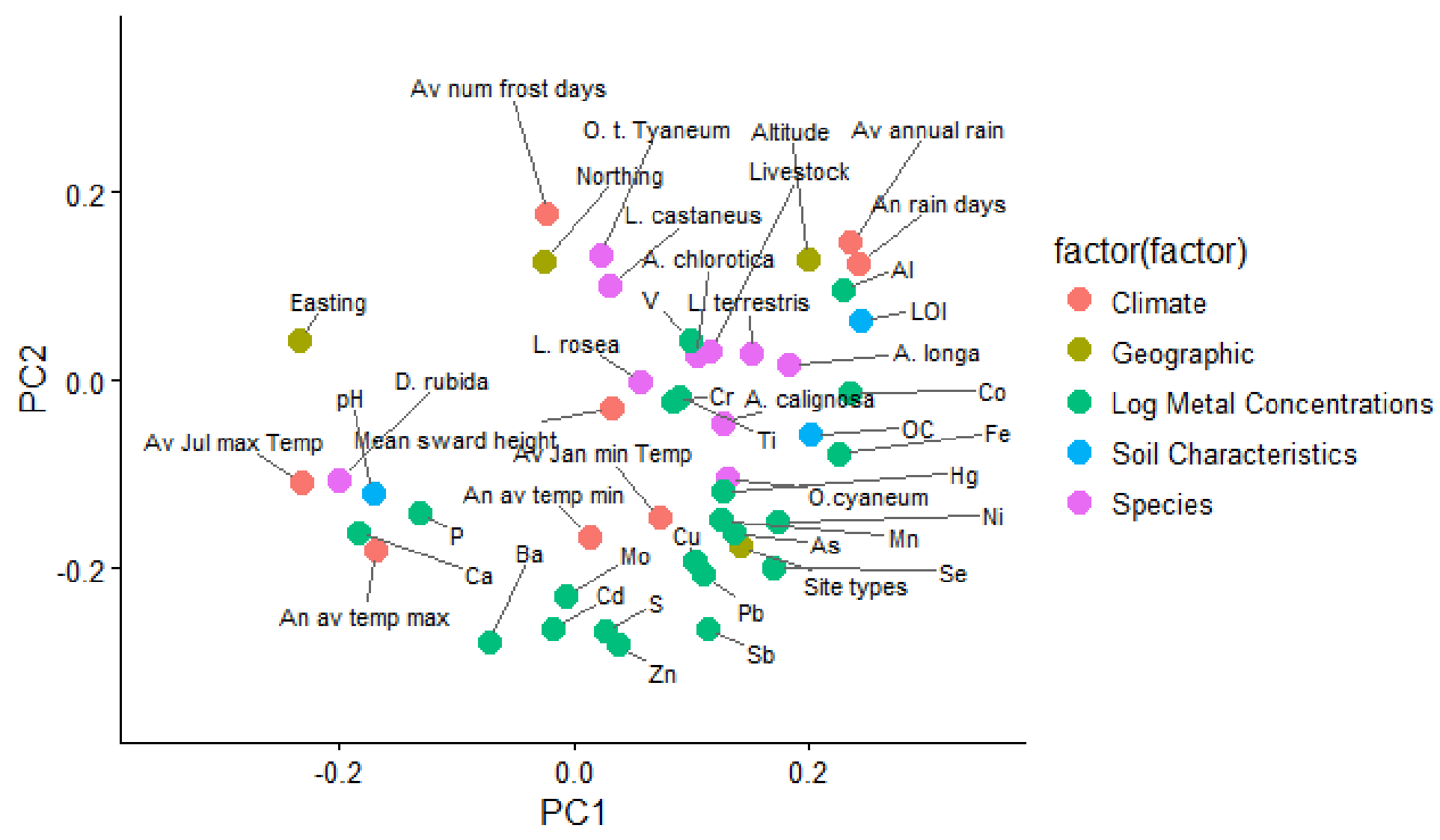


FIG. 3

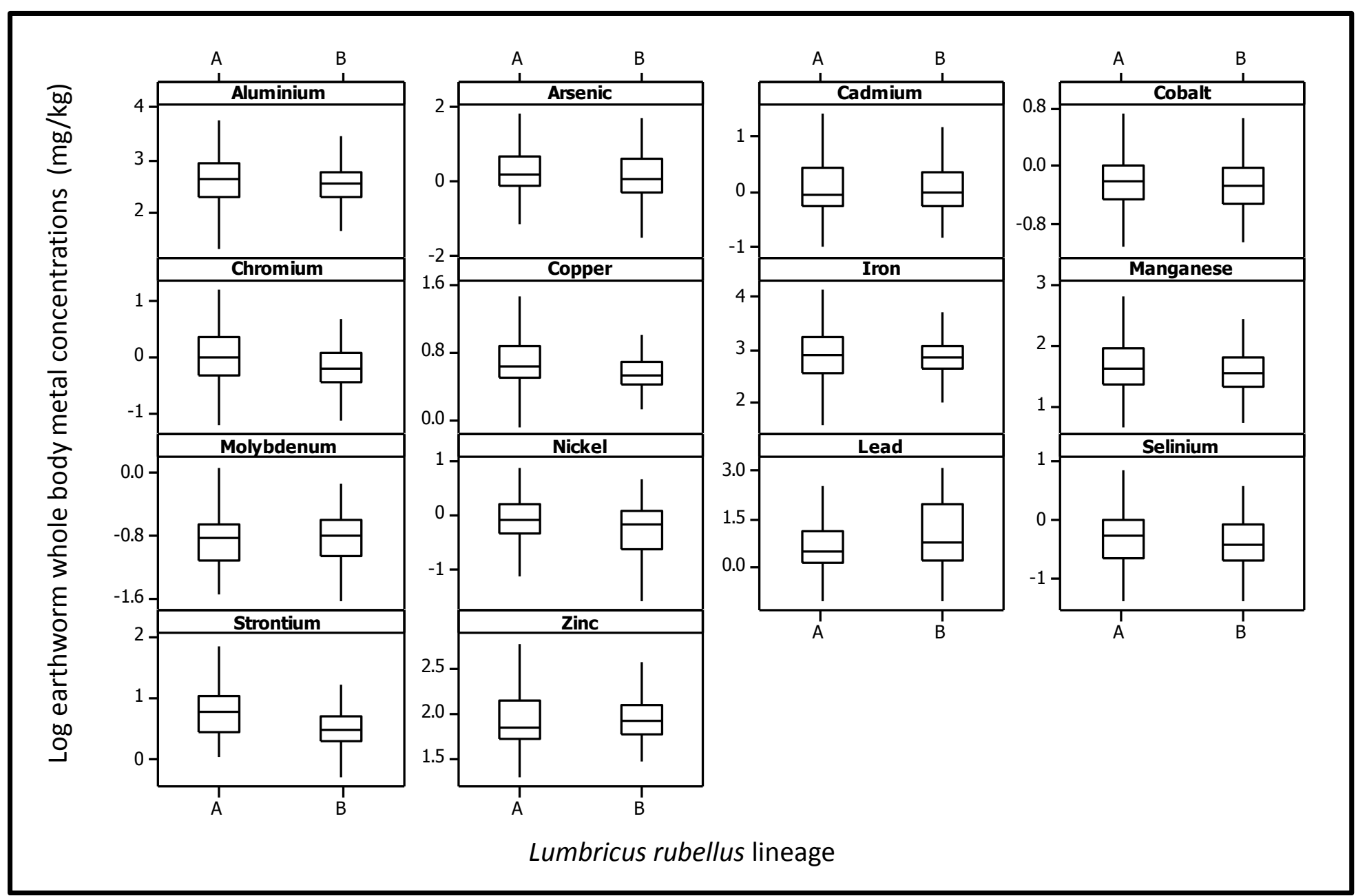


FIG. 4
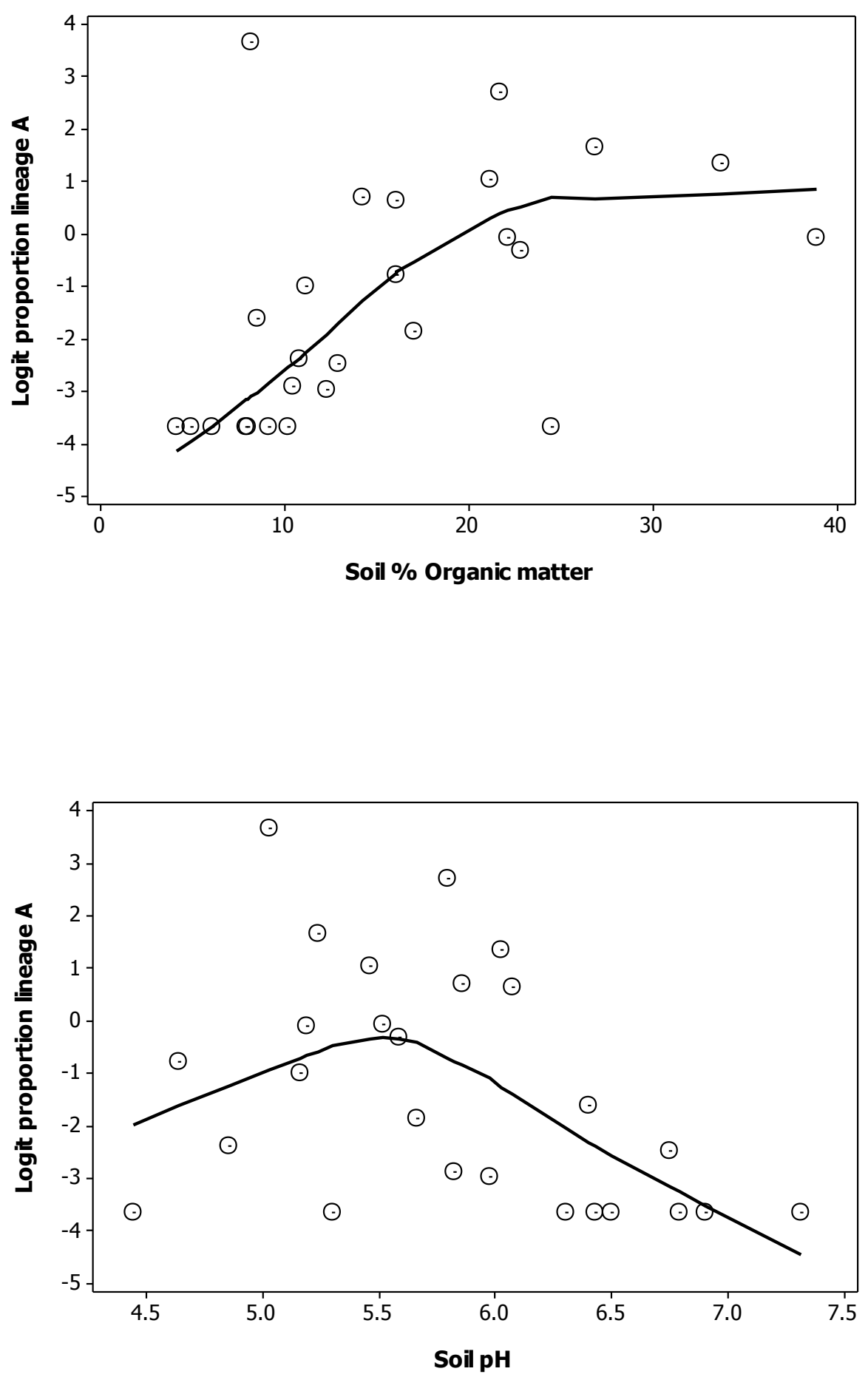


\section{SUPPLEMENTARY TABLES}

Supplementary Table 1. Geographical locations and reported climatic conditions of the 23 sites used for the collection of morphotype L. rubellus.

\begin{tabular}{|c|c|c|c|c|c|c|c|c|c|c|c|c|c|}
\hline Site name & Site types & Land use & 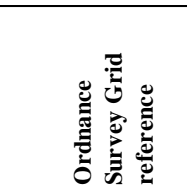 & 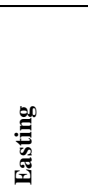 & 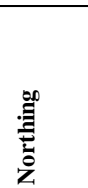 & 苋 & 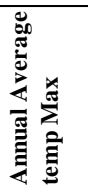 & 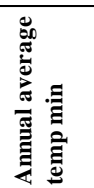 & 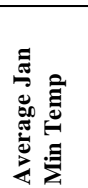 & 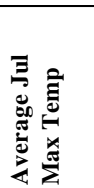 & 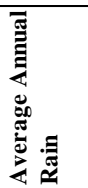 & 窇 & 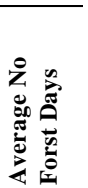 \\
\hline Alice Holt ECN Control & Unpolluted & Broadleaf woodland & SU 8006039821 & 480060 & 139821 & 88.6 & 14.1 & 6.4 & 1.6 & 21.9 & 755 & 121 & 45.9 \\
\hline Avonmouth Control & Unpolluted & Improved pasture & ST 5700682149 & 357006 & 182149 & 7 & 14.2 & 7 & 2.2 & 21.5 & 802 & 126 & 34.9 \\
\hline Avonmouth Incinerator & Industrial polluted & Rough grassland & ST 5409981659 & 354099 & 181652 & 6 & 14.2 & 7 & 2.2 & 21.5 & 802 & 126 & 34.9 \\
\hline Avonmouth Savalco & Industrial polluted & Rough grassland & ST 5385979411 & 353859 & 179411 & 6 & 14.2 & 7 & 2.2 & 21.5 & 802 & 126 & 34.9 \\
\hline Caradon Mine & Mining polluted & Rough grassland & SX 2562469792 & 225624 & 69792 & 226 & 13.2 & 7 & 3 & 19.1 & 1385 & 172 & 30.6 \\
\hline Carrick Fell Mine & Mining polluted & Rough grassland & NY 3221132982 & 332211 & 532982 & 661 & 13 & 5.8 & 1.6 & 19.7 & 1521 & 176 & 56.5 \\
\hline Castell Mine & Mining polluted & Rough grassland & SN 7741581254 & 277415 & 281254 & 297 & 11.9 & 5.2 & 1 & 18.2 & 186 & 191 & 58.4 \\
\hline Clydach Smelter & Industrial polluted & Broadleaf woodland & SN 6958701409 & 269587 & 201409 & 25 & 13.5 & 8.5 & 4 & 19.6 & 999 & 148 & 9.7 \\
\hline Cwmystwyth control & Unpolluted & Rough grassland & SN 7959874222 & 279598 & 274222 & 198 & 11.9 & 5.2 & 1 & 18.2 & 1856 & 191 & 58.4 \\
\hline Cwmystwyth mine & Mining polluted & Rough grassland & SN 8085275166 & 280852 & 275166 & 177 & 11.9 & 5.2 & 1 & 18.2 & 1856 & 191 & 58.4 \\
\hline Devon Great Consouls Control & Unpolluted & Improved pasture & SX 4256074019 & 242560 & 74019 & 133 & 14 & 8.1 & 4 & 19.9 & 1007.4 & 142 & 16.3 \\
\hline Devon Great Consouls Mine & Mining polluted & Broadleaf woodland & SX 4238573152 & 242385 & 73152 & 133 & 14 & 8.1 & 4 & 19.9 & 1007.4 & 142 & 16.3 \\
\hline Didcot Power Station & Industrial polluted & Broadleaf woodland & SU 5164591402 & 451645 & 191402 & 53 & 14.4 & 5.9 & 1.2 & 22.6 & 661 & 112 & 57.7 \\
\hline Drayton ECN Control & Unpolluted & Improved pasture & SP 1639155061 & 416391 & 255061 & 66 & 14.5 & 5.9 & 1.3 & 22.8 & 614 & 114 & 52.2 \\
\hline Dinas Powys & Unpolluted & Broadleaf woodland & ST 1586870431 & 315868 & 170431 & 57 & 14.7 & 7 & 2.3 & 21.7 & 1151.9 & 149 & 35.7 \\
\hline Ecton Mine & Mining polluted & Broadleaf woodland & SK 0969858263 & 409698 & 358263 & 103 & 13.9 & 6 & 1.2 & 22.1 & 598 & 112 & 49.1 \\
\hline Parys Mountain & Mining polluted & Rough grassland & SH 4382989971 & 243829 & 389971 & 117 & 13.2 & 7.7 & 3.6 & 18.8 & 841 & 143 & 20.3 \\
\hline Port Talbot Control & Unpolluted & Rough grassland & SS 8369084574 & 283690 & 184574 & 150 & 13.5 & 8.5 & 4 & 19.6 & 999 & 148 & 9.7 \\
\hline Port Talbot Blast Furnace & Industrial polluted & Rough grassland & SS 7900185463 & 279001 & 185463 & 6.1 & 13.5 & 8.5 & 4 & 19.6 & 999 & 148 & 9.7 \\
\hline Porton Down ECN & Unpolluted & Improved pasture & SU 1957537692 & 419575 & 137692 & 102 & 14.1 & 6.2 & 1.4 & 21.9 & 749 & 122 & 47.6 \\
\hline Roman Gravels Mine & Mining polluted & Rough grassland & SJ 3359200339 & 333592 & 300339 & 368 & 14.1 & 5.6 & 1.3 & 21.6 & 668 & 126 & 51.8 \\
\hline Scunthorpe blast furnace & Industrial polluted & Arable & SE 9480015840 & 494800 & 415835 & 19.7 & 13.4 & 5.7 & 0.9 & 21.3 & 613 & 115 & 49.8 \\
\hline Scunthorpe Control & Unpolluted & Arable & SE 9315612000 & 493156 & 412000 & 10.7 & 13.4 & 5.7 & 0.9 & 21.3 & 613 & 115 & 49.8 \\
\hline Shipham control & Unpolluted & Improved pasture & ST 4631259409 & 346312 & 159409 & 54 & 14.6 & 7 & 2.6 & 21.7 & 899 & 134 & 28.9 \\
\hline Shipham mine & Mining polluted & Improved pasture & ST 4479957273 & 344799 & 157273 & 169 & 14.6 & 7 & 2.6 & 21.7 & 899 & 134 & 28.9 \\
\hline Snowdown ECN control & Unpolluted & Rough grassland & SH 6367455116 & 263674 & 355116 & 748 & 12 & 5.9 & 1.8 & 18.1 & 2612 & 199 & 50.1 \\
\hline
\end{tabular}


Supplementary Table 2. Vegetation and presence (shaded) or absence (unshaded) for earthworm species at the 23 sites used for the collection of morphotype L. rubellus.

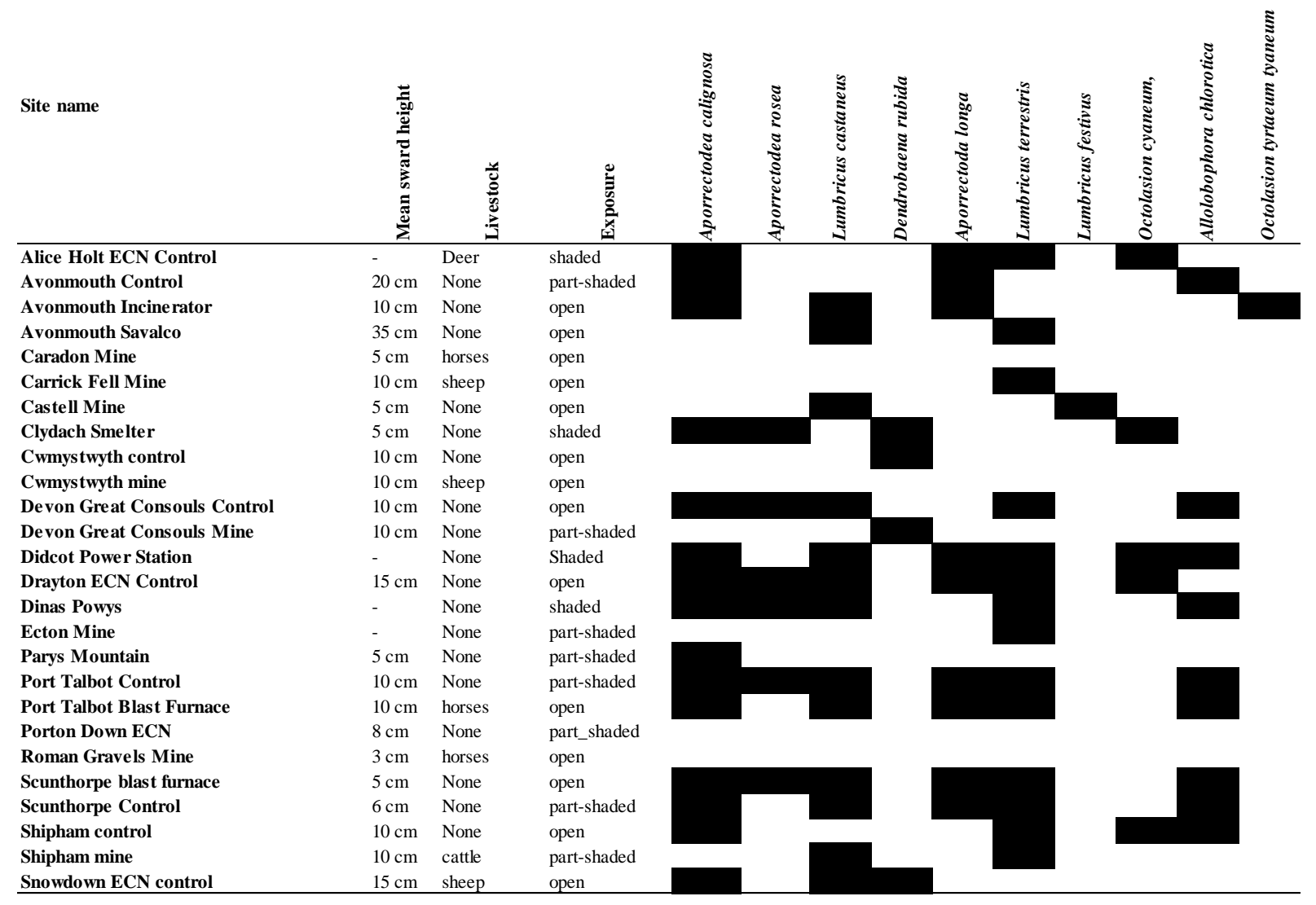


Supplementary Table 3. Arithmetic mean of measured soil chemical properties for $\mathrm{pH}$, loss on ignition and concentrations of a suite of trace lements based on analysis of three samples collected from sites the 23 sites used for the collection of morphotype $L$. rubellus.

\begin{tabular}{|c|c|c|c|c|c|c|c|c|c|c|c|c|c|c|c|c|c|c|c|c|c|c|c|}
\hline Site name & $\begin{array}{l}\text { 总 } \\
\overline{\overline{8}}\end{array}$ & 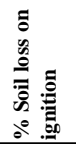 & 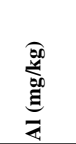 & 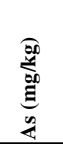 & 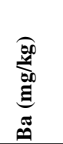 & 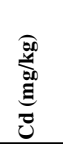 & 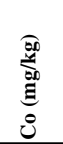 & 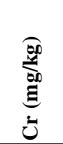 & 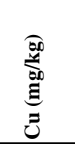 & 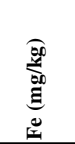 & 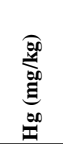 & 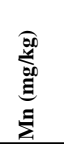 & 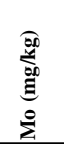 & 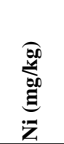 & 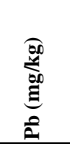 & 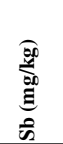 & 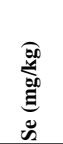 & 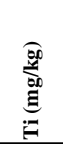 & 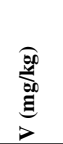 & 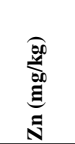 & 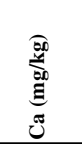 & 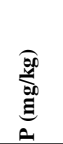 & 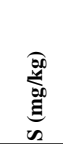 \\
\hline Alice Holt ECN Control & 5.16 & 11.15 & 8737 & 13.2 & 19.3 & 0.1 & 6 & 12.6 & 12.4 & 16500 & 0.17 & 78 & 0.3 & 9.5 & 27.1 & 0.4 & 0.5 & 7 & 24.6 & 43 & 1640 & 424 & 202 \\
\hline Avonmouth Control & 5.86 & 14.23 & 11130 & 20.9 & 356 & 2.3 & 10 & 46.3 & 75.1 & 26133 & 0.76 & 539 & 1.2 & 25.1 & 207 & 1.3 & 1.7 & 32.9 & 26.9 & 697 & 68633 & 524 & 1029 \\
\hline Avonmouth Incine rator & 6.5 & 7.94 & 11000 & 36.9 & 439 & 50.6 & 12.3 & 23.6 & 204.3 & 26133 & 1.07 & 1010 & 2 & 25.7 & 1943 & 14.9 & 5.6 & 34.4 & 31.8 & 4640 & 39267 & 1600 & 3190 \\
\hline Avonmouth Savalco & 6.3 & 24.51 & 14733 & 7.8 & 75.1 & 2.6 & 8.1 & 25.1 & 29.8 & 19233 & 0.25 & 663 & 0.6 & 18.4 & 99.6 & 1.2 & 0.6 & 95.5 & 29.6 & 299 & 4777 & 1233 & 734 \\
\hline Caradon Mine & 4.64 & 16 & 5147 & 407 & 33.7 & 1.17 & 2.03 & 3.9 & 609 & 20633 & 0.33 & 221 & 2.57 & 4.27 & 69.1 & 3.17 & 1.49 & 27.4 & 13.8 & 43.5 & 342 & 776 & 884 \\
\hline Carrick Fell Mine & 4.85 & 10.8 & 16300 & 737 & 33.5 & 3.07 & 8.18 & 16.4 & 59 & 33300 & 2.06 & 837 & 18.10 & 11.4 & 173 & 7.01 & 3.85 & 165 & 92.6 & 282 & 1607 & 961 & 1457 \\
\hline Castell Mine & 5.03 & 8.15 & 14333 & 14.7 & 15.7 & 9.03 & 12.5 & 16.4 & 60 & 46267 & 0.5 & 844 & 1.16 & 16.5 & 210 & 2.28 & 1.35 & 8.1 & 26.8 & 1792 & 321 & 506 & 312 \\
\hline Clydach Smelter & 5.3 & 10.2 & 6780 & 44.1 & 142 & 1.61 & 90.1 & 32.3 & 465 & 25067 & 0.34 & 1369 & 2.68 & 1799 & 278 & 3.57 & 14.43 & 70.9 & 47.2 & 370 & 39277 & 945 & 1230 \\
\hline Cwmystwyth control & 5.23 & 26.89 & 16167 & 19.8 & 14.6 & 0.1 & 6.7 & 18.7 & 19.7 & 38033 & 0.12 & 467 & 0.9 & 14.3 & 626 & 1.6 & 1.2 & 6.6 & 24.6 & 116 & 209 & 688 & 709 \\
\hline Cwmystwyth mine & 5.46 & 21.13 & 20033 & 49 & 29.8 & 0.2 & 41.2 & 24.1 & 28.8 & 50433 & 112 & 2597 & 1.5 & 23.3 & 657 & 2.5 & 1.4 & 22 & 33.3 & 127 & 551 & 689 & 534 \\
\hline Devon Great Consols Control & 5.58 & 22.79 & 21533 & 310 & 45.5 & 0.4 & 14.8 & 31.7 & 107.3 & 45800 & 0.05 & 585 & 1 & 27.5 & 68 & 1.4 & 2.3 & 41.8 & 38.7 & 140 & 2213 & 1177 & 919 \\
\hline Devon Great Consols Mine & 5.19 & 38.9 & 17300 & 6270 & 45.9 & 0.2 & 25.7 & 17.8 & 2647 & 79600 & 0.64 & 630 & 1.3 & 22.3 & 225 & 13.9 & 2.6 & 38.4 & 38.5 & 277 & 3340 & 286 & 1503 \\
\hline Didcot Power Station & 7.31 & 4.17 & 10570 & 14.5 & 139 & 0.53 & 8.89 & 14.7 & 41 & 22900 & 0.34 & 309 & 0.93 & 24.1 & 102 & 2.42 & 1.40 & 15.1 & 26.9 & 181.00 & 37600 & 901 & 1250 \\
\hline Drayton ECN Control & 5.79 & 21.65 & 12833 & 25.1 & 48.4 & 0.4 & 4.9 & 15.8 & 46 & 28533 & 0.1 & 805 & 2.3 & 10.7 & 30.2 & 0.6 & 0.5 & 34.3 & 32 & 176 & 35000 & 2000 & 1183 \\
\hline Dinas Powys & 6.9 & 8 & 17166 & 23 & 85.4 & 1.2 & 16.1 & 39 & 42.6 & 24933 & 0.1 & 1120 & 1.7 & 45.1 & 109 & $*$ & 1.2 & 41.5 & 45.7 & 770 & 12766 & 2070 & $*$ \\
\hline Ecton Mine & 5.82 & 10.4 & 1403 & 136 & 537 & 61.4 & 33.2 & 5.4 & 5787 & 12267 & 0.35 & 965 & 101 & 72.4 & 1553 & 92.1 & 5.42 & 20.1 & 20.2 & 6047 & 116200 & 203 & 9280 \\
\hline Parys Mountain & 4.44 & 4.95 & 681 & 1480 & 96 & 8.77 & 7.78 & 5 & 3673 & 175667 & 3.34 & 35.7 & 37.5 & 3.17 & 29033 & 210 & 42 & 54.4 & 19 & 2333 & 1749 & 26.7 & 22467 \\
\hline Port Talbot Control & 5.66 & 16.99 & 15300 & 14.5 & 127 & 0.6 & 11.3 & 37.7 & 33.8 & 31467 & 0.27 & 1287 & 0.9 & 17.4 & 39.1 & 0.8 & 1.2 & 15.7 & 62.9 & 480 & 13903 & 1427 & 1083 \\
\hline Port Talbot Blast Furnace & 5.98 & 12.3 & 10323 & 14.5 & 287 & 0.8 & 4.7 & 129 & 35.5 & 34967 & 0.33 & 3550 & 1.7 & 16.8 & 117 & 2.2 & 1.1 & 230.7 & 140 & 341 & 89133 & 1227 & 1680 \\
\hline Porton Down ECN & 6.75 & 12.93 & 6153 & 21 & 88.3 & 0.7 & 8 & 20 & 39.2 & 13567 & 0.37 & 611 & 0.9 & 17.3 & 109 & 1.4 & 0.5 & 46.3 & 17.2 & 184 & 148333 & 3100 & 1423 \\
\hline Roman Gravels Mine & 6.4 & 8.48 & 10633 & 13.7 & 123 & 14.2 & 14.3 & 13.3 & 99 & 30133 & 0.33 & 582 & 1.17 & 24.8 & 1125 & 2.48 & 1.33 & 15.7 & 18.4 & 1788 & 6367 & 455 & 878 \\
\hline Scunthorpe blast furnace & 6.43 & 9.14 & 10803 & 40.6 & 90.3 & 0.3 & 13.1 & 42 & 25.4 & 59900 & 0.33 & 1227 & 1.5 & 29.5 & 124 & 1.8 & 1 & 68.3 & 128.7 & 183 & 13500 & 1497 & 453 \\
\hline Scunthorpe Control & 6.79 & 6.04 & 7197 & 24.6 & 47.4 & 0.4 & 4.9 & 15.4 & 20.2 & 21767 & 0.12 & 535 & 2.3 & 11.2 & 30.0 & 0.6 & 0.5 & 33.6 & 30.7 & 69.1 & 130667 & 1253 & 1167 \\
\hline Shipham control & 6.07 & 16.1 & 12967 & 37.1 & 302 & 2.1 & 7.5 & $\begin{array}{l}23.1 \\
23.1\end{array}$ & 19.1 & 26500 & 0.03 & 465 & 0.7 & 16.4 & 163 & 0.9 & 0.4 & 53.9 & 34.8 & 328 & 3520 & 972 & 584 \\
\hline Shipham mine & 6.03 & 33.7 & 9907 & 867 & 1526 & 404 & 12.5 & 21 & 85.1 & 85100 & 12.3 & 2277 & 5.1 & 31.6 & 7260 & 48.8 & 3.8 & 51.4 & 28.5 & 31833 & 16117 & 2370 & 3547 \\
\hline Snowdown ECN control & 5.52 & 22.07 & 38600 & 17.5 & 10.1 & 0.3 & 30.6 & 78.2 & 19.5 & 70733 & 0.19 & 1350 & 0.5 & 30.4 & 37 & 0.5 & 1.4 & 1530 & 239 & 114 & 1111 & 524 & 658 \\
\hline
\end{tabular}

